\title{
Analisis Data Panel Pengaruh PDRB, BI Rate dan IPM Terhadap Tabungan Bank
}

\author{
Muhammad Arfan Harahap ${ }^{1 *}$, Muhammad Hafizh ${ }^{2}$, Anjur Perkasa Alam ${ }^{3}$ \\ 1,2,3 STAI Jam'iyah Mahmudiyah, Tanjung Pura, Langkat, Indonesia.
}

\begin{abstract}
Abstrak. Tabungan berperan penting dalam peningkatan ekonomi nasional maupun regional. Penelitian ini bertujuam menganalisis pengaruh PDRB, BI Rate dan IPM terhadap tabungan pada Bank baik secara parsial maupun simultan. Analisis data panel digunakan terbadap data di Provinsi Sumatera Utara dengan variabel penelitian yang identic. Penggunaan data skunder pada penelitian ini berdasarkan pada data time series dan cross section dari tabun 2010-2020. Selain itu, untuk melibat pengaruh variabel penelitian kbusus di Kabupaten Langkat digunakan model regresi linier berganda. Data diolah dengan bantuan program eviews versi.11 dan lulus uji masalah asumsi klasike serta uji normalitas data. Temuan awal dalam penelitian ini adalab variabel IPM berpengaruh signifikan pada tabungan pada bank di Sumatera Utara, Sedangkan variabel BI Rate dan PDRB tidak berpengarub terbadap tabungan, namun pada taraf signifikansi 10\% untuk variabel BI Rate berpengaruh. Temuan lanjutan yaitu terdapat pengaruh signifikean variabel PDRB dan IPM terbadap Tabungan masyarakat di Kabupaten Langkat. Sedangkan variabel BI Rate tidak berpengarub terbadap Tabungan masyarakat Kabupaten Langkat. Secara simultan selurub variabel bebas penelitian berpengarub terhadap variabel terikat.
\end{abstract}

Kata kunci: PDRB; BI Rate; IPM; Tabungan.

Abstract. Savings play an important role in improving the national and regional economy. This study aims to analyze the effect of PDRB, BI Rate and IPM on savings at the Bank either partially or simultaneously. Panel data analysis was used for data in North Sumatra Province with identical research variables. The use of secondary data in this study is based ondata time series and cross section from 2010-2020. In addition, to see the effect of specific research variables in Langkat Regency, multiple linear regression models are used. The data was processed with the belp of the eviews version 11 program and passed the classic assumption problem test and the data normality test. The initial findings in this study are that the IPM variable has a significant effect on savings at banks in North Sumatra, while the BI Rate and PDRB variables have no effect on savings, but at a significance level of $10 \%$, the BI Rate variable has an effect. Further findings are that there is a significant effect of the PDRB and IPM variables on public savings in Langkat Regency. Meanwhile, the BI Rate variable has no effect on the Langkeat Regency community savings. Simultaneously all independent variables of the study affect the dependent variable.

Keywords: PDRB; BI Rate; IPM; Savings. 


\section{Pendahuluan}

Tabungan merupakan determinan penting dari pertumbuhan ekonomi (Mori, 2019). Kekurangan tabungan nasional yang merupakan salah satu kendala paling kritis pada pertumbuhan ekonomi dan tabungan nasional yang tinggi kemungkinan akan merangsang investasi nasional, yang pada gilirannya akan memberikan dasar bagi pertumbuhan ekonomi yang lebih cepat pertumbuhan (Narayan \& Narayan, 2006). Selain itu tabungan domestik juga memainkan peran penting dalam pembangunan berkelanjutan dan ekonomi kinerja negaranegara (Duran et al., 2017). Bagi individu, menabung membantu menyediakan kebutuhan pribadi dan rumah tangga di masa depan. Tabungan juga berfungsi untuk memenuhi kebutuhan keadaan yang tak terduga. Menabung merupakan bagian dari pendapatan yang diperoleh individu. Manfaat tabungan meliputi; lindung nilai terhadap keadaan yang tidak terduga, membangun aset, mempersiapkan peluang investasi, menyediakan kebutuhan dana pensiun, membeli atau meningkatkan tempat tinggal, melunasi hutang dan memperoleh layanan sosial, dimana tujuan utama menabung adalah untuk pengeluaran masa pensiun (Suppakitjarak \& Krishnamra, 2015).

Menabung sangat penting untuk kesehatan ekonomi dan rumah tangga. Rata-rata tingkat tabungan adalah antara 8\% dan 12\% dari pendapatan tahunan. Rumah tangga lebih muda menabung lebih sedikit dari pada rumah tangga yang lebih tua. Rumah tangga dengan lebih lama karir yang diharapkan, rata-rata, menabung lebih sedikit (Bodenhorn, 2018). Pentingnya menabung telah lama diakui dalam sejarah umat manusia baik dari segi agama maupun ekonomi (Haron \& Nursofiza Wan Azmi, 2008). Di Indonesia, Sumber dana bank berasal dari dana bank itu sendiri, dana dari masyarakat dan dana pinjaman. Sumber dana bank di Indonesia terus mengalami peningkatan positif (Fuadi \& Munandar, 2020). Berdasarkan data Statistik Perbankan Indonesia pada tahun 2018 sumber dana bank umum sebesar 6.475.110 (dalam milyar), selanjutnya di tahun 2019 meningkat menjadi 6.839.563 (dalam milyar) dan ditahun 2020 sebesar 7.405.325 (dalam milyar). Jumlah sumber dana bank tersebut didominasi dana dari masyarakat atau dana pihak ketiga (DPK). Dana Pihak ketiga bank ini terdiri dari Tabungan Giro, Tabungan dan Deposito berjangka. DPK bank pada tahun 2018 sebesar 5.630.448, selanjutnya tahun 2019 terjadi peningkatan 5.998.648 dan ditahun 2020 sebesar 6.665.390. Tercatat dana pihak ketiga bank ditahun 2020 mencapai 90,01\% dari total sumber dana bank. Selain itu, dalam tiga dekade terakhir pertumbuhan aset perbankan khususnya perbankan syariah di Indonesia meningkat luar biasa di lebih dari 500 persen, yang hanya sekitar Rp 479 miliar pada tahun 1998 menjadi Rp.250.755 miliar pada tahun 2018. Terlepas dari kinerja yang mengesankan, data menunjukkan bahwa telah terjadi fluktuasi pertumbuhan aset dan dana pihak ketiga sejak 2013 hingga 2018 (Yumna, 2019).

Tabungan merupakan bagian simpanan sementara dan tidak stabil yang dapat ditarik sewaktu-waktu oleh nasabah, sedangkan deposito merupakan bagian simpanan bank yang permanen dan stabil (Harun \& Nattan, 2019). Bank mengandalkan deposito untuk memperpanjang kredit, karena ini adalah pendanaan yang stabil. Namun dalam kondisi normal, simpanan berfluktuasi sesuai dengan kegiatan ekonomi. Bank kemudian dikenakan risiko likuiditas ketika mereka tidak dapat mengantisipasi kemungkinan penarikan deposito sejumlah bagian yang tidak stabil dari deposit. Sehingga prinsip-prinsip good corporate governance (GCG) dapat diimplementasikan untuk meningkatkan laba (Riyanto et al., 2021). Terdapat berbagai faktor yang mempengaruhi kemampuan dan kemauan untuk menabung. (Tobing, 2014) dalam penelitiannya diperoleh kesimpulaan bahwa Produk Domestik Bruto dan tingkat suku bunga berpengaruh positif terhadap tingkat tabungan, sedangkan inflasi berpengaruh negatif terhadap tingkat tabungan. Sedangkan (Klasjok et al., 2018) hasil penelitiannya menunjukan bahwa tingkat suku bunga berpengaruh negatif dan signifikan terhadap tabungan masyarakat di papua barat, PDRB berpengaruh positif dan signifikan terhadap tabungan masyarakat di papua barat, sedangkan tingkat inflasi berpengaruh positif dan signifikan terhadap tabungan masyarakat di papua barat. 
Penelitian (Amari et al., 2020) bahwa perubahan pertumbuhan kompleksitas sektor keuangan dan penurunan tabungan pribadi, sementara hutang yang semakin meningkat, menjadi faktor yang membuat edukasi keuangan semakin meningkat penting. Faktor lain yang mempengaruhi tabungan adalah Pengetahuan, keterampilan, keyakinan mempengaruhi sikap dan perilaku untuk menabung. Produk keuangan dan layanan menjadi lebih kompleks dan tidak mudah dipahami oleh banyak konsumen. Oleh karena itu, konsumen dengan literasi keuangan rendah dapat menghadapi kesulitan untuk membuat keputusan tentang tabungan dan investasi mereka (Zakaria \& Ismail, 2017).

Terdapat gap penelitian terdahulu dan gap teori dan empiris mengenai factor-faktor yang mempengaruhi tabungan masyarakat di bank. Sehingga menjadi sangat menarik dan penting untuk diteliti menganai factor-faktor yang mempengaruhi tabungan masyarakat pada bank di Provinsi Sumatera Utara dan khususnya Kabupaten Langkat untuk mendapatkan kebaharuan data.

\section{Literature Review}

Kebanyakan teori tabungan lebih didasarkan pada tingkat tabungan agregat dari pada pada proses menabung dan konteks pemasaran penabung (Earl, 2001). Dalam ekonomi, tabungan rumah tangga terutama diperlakukan sebagai sisa, dan bukan sebagai primer aktivitas. Menyimpan adalah pengorbanan (Oberholster, 2010). Tabungan bisa dicuri, dijarah, tapi dapat digunakan untuk melindungi dari masa depan yang tidak pasti. Teori Model siklus hidup normatif dan mengklarifikasi bahwa modalitas pendapatan masa depan yang diantisipasi adalah penting dalam perilaku tabungan yang bersangkutan. Tinjauan komprehensif dari prediksi kunci dari hipotesis siklus hidup dan studi yang mengadopsi teori ini. Modalitas tabungan rumah tangga telah mengadopsi ukuran keragaman tabungan, serta pengeluaran relatif terhadap pendapatan.

Ekonomi ada untuk memenuhi kebutuhan individu. Namun individu memiliki keterbatasan rentang hidup dan dengan demikian pendapatan yang terbatas selama rentang hidup itu. Orang-orang yang mengkonsumsi melebihi batas pendapatan dari pada produksi mereka akan menghasilkan defisit. Menabung merupakan bagian penting dari pengambilan keputusan keuangan konsumen. Dibandingkan dengan produk lainnya, produk tabungan sering dianggap lebih kompleks dan sulit untuk dievaluasi karena terhadap kecanggihan, ketidakpastian, dan cakrawala jangka panjang mereka. Oleh karena itu, banyak konsumen memutuskan untuk menabung setelah berkonsultasi dengan penasihat keuangan (Eriksson \& Hermansson, 2019). Dalam konteks ekonomi, tabungan biasanya merupakan sebagai kelebihan pendapatan atas konsumsi, pengeluaran dalam suatu periode, atau sebagai selisih kekayaan bersih pada akhir periode dan bernilai pada awal periode. Kedua definisi tersebut memperlakukan menabung sebagai residu dan bukan sebagai aktivitas utama, secara psikologis menabung sebagai suatu kegiatan atau kegiatan proses (Eriksson \& Hermansson, 2014).

Masyarakat yang memiliki uang surplus akan dihadapkan kepada pilihan untuk menyimpan uangnya di bank atau menyimpannya sendiri. Disamping itu masyarakat yang memiliki surplus dana akan dihadapkan pada pilihan menyimpan uangnya di bank atau menginvestasikan uangnya dalam bentuk asset lainnya yang memberikan keuntungan. Pendapatan masyarakat menjadi faktor penting dalam membuat keputusan terhadap pilihan tersebut. Dari pendapatan yang dihasilkan masyarakat akan digunakan terlebih dahulu untuk keperluan sehari-hari, sisanya akan disimpan dalam bentuk tabungan. Secara agregat pendapatan/ PDRB memberikan pengaruh terhadap jumlah tabungan yang akan dilakukan masyarakat (Harahap \& Hafizh, 2020).

Kenaikan BI Rate yang diikuti dengan kenaikan suku bunga kredit bank dapat menyebabkan meningkatnya minat masyarakat dalam menabung di bank. Ketika BI rate meningkat masyarakat akan lebih cendrung menabung dibank dibandingakan dengan melakukan investasi rill yang memiliki risiko lebih tinggi. Suku bunga bank sangat mempengaruhi minat 
masyarakat untuk menabung. Dimana fungsi tabungan jangka panjang yang sensitif terhadap perubahan tingkat bunga riil, likuiditas dan keuangan public (Hondroyiannis, 2004). IPM dalam penelitian ini menggambarkan pengetahuan atau literasi terkait lembaga keuangan memberikan pengaruh terhadap keputusan untuk menabung di bank. Dimana literasi keuangan merupakan kemampuan untuk membuat keputusan keuangan berdasarkan pengetahuan yang memadai tentang konsep dan instrumen keuangan (Sara Jonsson Inga-Lill Söderberg Mats Wilhelmsson, 2017). Hasil penelitian menunjukkan bahwa UMKM yang memiliki literasi keuangan yang baik akan mampu membuat strategi yang solutif dan terarah dengan baik untuk kedepannya (Ariyati et al., 2021). Di awali dengan pengetahuan dan kemudian dengan pengalaman penggunaan jasa lembaga keuangan akan meningkatkan kepercayaan masyarakat untuk menempatkan dananya ke bank. Pengetahuan mendorong Tabungan berpengaruh positif terhadap keputusan menabung nasabah.

\section{Metodologi Penelitian}

Jenis penelitian kuantitatif dengan menggunakan data skunder digunakan dalam penelitian ini. Analisis data panel digunakan untuk melihat pengaruh variabel PDRB, BI rate dan IPM terhadap variabel Tabungan di Sumatera Utara di lanjutkan dengan regresi linier berganda untuk melihat secara khusus pengaruh variabel eksogen terhadap variabel endogen di Kabupaten Langkat. Data penelitian di mulai dari tahun 2010 - 2020 dengan data time series dan data cross section. Uji masalah asumsi klasik menjadi persyaratan dalam penelitian ini. Adapun hipotesis pada penelitian ini sebagai berikut:

$\mathrm{H}_{1}$ : Produk Domestik Regional Bruto berpengaruh signifikan terhadap tabungan

$\mathrm{H}_{2}$ : $\mathrm{BI}$ rate berpengaruh signifikan terhadap tabungan

$\mathrm{H}_{3}$ : IPM berpengaruh signifikan terhadap tabungan

$\mathrm{H}_{4}$ : Secara simultan PDRB, BI rate dan IPM berpengaruh signifikan terhadap Tabungan.

\section{Hasil dan Pembahasan}

\section{Deskripsi Data Penelitian}

Statistik deskriptif data penelitian memberikan gambaran pada suatu data. Hasil analisis statistik deskriptif penelitian ini sebagai berikut:

Tabel 1. Analisis Statistik Deskriptif

\begin{tabular}{|l|l|c|c|c|}
\hline & Tabungan & PDRB & BI & IPM \\
\hline Mean & 1346492. & 31168.36 & 5.886364 & 68.29091 \\
\hline $\begin{array}{l}\text { Maxim } \\
\text { um }\end{array}$ & 1868783. & 43208.00 & 7.750000 & 71.00000 \\
\hline $\begin{array}{l}\text { Minim } \\
\text { um }\end{array}$ & 1022486. & 18386.00 & 3.750000 & 64.57000 \\
\hline $\begin{array}{l}\text { Std. } \\
\text { Dev. }\end{array}$ & 359476.4 & 8806.903 & 1.357220 & 2.155200 \\
\hline
\end{tabular}

Terdapat empat variabel dalam penelitian ini, dimana variabel endogen adalah Tabungan. Nilai maksimum variabel tabungan adalah 1868783, sedangkan nilai minimumnya sebesar 1022486 dengan standart dev sebesar 359476. Sedangkan variabel eksogen terdiri dari variabel PDRB dengan nilai maksimun sebesar 43208,00 dan nilai minimum sebesar 18386,00 dengan standart dev sebesar 8806,903. Variabel Bi Rate dengan nilai maksimum 7.750000,- dan nilai minimum 3.75000,- serta nilai standart dev 1.357220. Variabel IPM dengan nilai maksimum 71.00000 ,- dan nilai minimum 64.570000,dengan standart dev 2.155200,-.

Analisis Data

\section{Uji Normalitas}

Untuk melihat tingkat normalitas data penelitian, dapat dilakukan dengan berbagai cara antara lain; dengan melihat hasil grapik histogram variabel dan nilai probabilitas masing-masing variabel. Tampilan dengan grapik histogram sering kali membentuk pola yang tidak mengikuti bentuk kurva normal, sehingga sulit disimpulkan. Oleh karena itu untuk melihat normalitas masing masing penelitian dapat dilakukan dengan melihat nilai koefisien jargue-bera (J-B) dan nilai probabilitas masing-masing variabel. Berdasarkan output hasil uji normalitas menggunakan program eviews 11, dapat dilihat nilai jarque-Bera sebesar 0,302825 dengan nilai probabilitas sebesar 0.859493 lebih besar dari $\alpha=5 \%$, berdasarkan rule of thumb dimana apabila Prob (Jarque-Bera) lebih besar dari $\alpha=5 \%$ maka data yang digunakan dapat dikatakan berdistribusi normal. 


\section{Uji Asumsi Klasik}

Multikolinieritas

Masalah multikolinieritas dideteksi dari nilai R2 yang sangat tinggi yaitu mencapai 99\%, sementara banyak variabel independen pada penelitian ini yang signifikan. Nilai R-squared yang diperoleh dari hasil regresi data 0.977172 dan lebih banyak variabel bebas yang nilai prob yang signifikan yaitu variabel PDRB sebesar 0.0008 dan variabel IPM sebesar 0.0060 sedangkan variabel BI rate sebesar 0.9089. Berdasarkan hasil tersebut, maka dapat dinyatakan bahwa data pada variabel penelitian telah terbebas dari masalah klasik multikolinieritas.

\section{Autokorelasi}

Masalah autokorelasi pada penelitian ini dapat dilihat dari nilai Durbin Watson (D-W) yang menunjukkan angka D-W sebesar 2.318566. Angka D-W menunjukkan berada pada area diterima Ho yang berarti tidak ada autokorelasi. karena nilai D-W sebesar 2.318566 berada diantara 2,359 sampai 1,641. Oleh karena itu, data pada penelitian ini bebas dari masalah autokorelasi.

\section{Uji Statistik}

Uji statistik pada penelitian ini dilakukan dengan model regresi linier berganda dengan menggunakan program eviews.11 dengan hasil sebagai berikut :

Tabel 2. Hasil Uji Statistik

Dependent Variable: TABUNGAN

Method: Least Squares

Date: 08/04/21 Time: 12:22

Sample: 20102020

Included observations: 11

\begin{tabular}{crlll}
\hline \multicolumn{1}{c}{ Variable } & Coefficient & Std. Error & t-Statistic & Prob. \\
\hline \hline C & 18340981 & 4581593. & 4.003188 & 0.0052 \\
PDRB & 111.7942 & 20.03857 & 5.578948 & 0.0008 \\
BI & 2685.591 & 22637.12 & 0.118637 & 0.9089 \\
IPM & -300109.3 & 77158.08 & -3.889539 & 0.0060 \\
\hline \hline & & & & \\
R-squared & 0.977172 & Mean dependent var & 1346492. \\
Adjusted R-squared & 0.967389 & S.D. dependent var & 359476.4 \\
S.E. of regression & 64916.25 & Akaike info criterion & 25.27487 \\
Sum squared resid & $2.95 \mathrm{E}+10$ & Schwarz criterion & 25.41956 \\
Log likelihood & -135.0118 & Hannan-Quinn criter. & 25.18366 \\
F-statistic & 99.88119 & Durbin-Watson stat & 2.318566 \\
Prob(F-statistic) & 0.000004 & & & \\
\hline \hline
\end{tabular}

Berdasarkan hasil regres diatas, pengujian terhadap masing-masing hipotesis yiang diajukan dapat dilakukan dengan cara :
Uji Model dengan koefisien determinan $\mathrm{R}^{2}$

Berdasarkan tabel diatas, diketahui bahwa nilai $\mathrm{R}^{2}$ sebesar 0.977172 artinya variabel bebas didalam model regresi mampu menjelaskan variabel terikat sebesar $97 \%$, sedangkan sisanya $0,3 \%$ dipengaruhi variabel lain. Nilai $\mathrm{R}^{2}$ yang telah disesuaikan (Adjusted R-Squared) sebesar 0.967389 atau $96 \%$.

\section{Uji Parsial dengan t-Test}

Uji parsial penelitian ini dapat dilakukan dengan meihat nilai probabilitas dan nilai $\mathrm{T}_{\text {hitung }}$. Nilai derajat bebas penelitian ini adalah 11-3=9, maka $T_{\text {tabel }}$ sebesar 1,796. Berdasarkan nilai ini maka hipotesis peneilian ini terjawab sebagai berikut :

1. $\mathrm{T}_{\text {hitung }}(5,578948)<\mathrm{T}_{\text {tabel }}(1,796)$ dan probabilitas $(0.0008)>(0,05)$ maka $\mathrm{H}_{\circ}$ ditolak, artinya PDRB memiliki pengaruh yang sangat signifikan terhadap Tabungan.

2. $\mathrm{T}_{\text {hitung }}(0,118637)<\mathrm{T}_{\text {tabel }}(1,796)$ dan probabilitas $(0,9089)<(0,05)$ maka $\mathrm{H}_{\circ}$ diterima, artinya BI Tidak memiliki pengaruh yang signifikan terhadap Tabungan.

3. $\mathrm{T}_{\text {hitung }}(-3.889539)>\mathrm{T}_{\text {tabel }}(1,796)$ dan probabilitas $(0.0060)>(0,05)$ maka $H_{\circ}$ ditolak, artinya IPM memiliki pengaruh yang sangat signifikan terhadap Tabungan.

\section{Uji simultan dengan F-Test}

Uji dilakukan dengan melihat nilai $\mathrm{F}$ dan nilai probabilitas. maka df1 $=5-1=4$, dan df2 $=11$ $3=9$ sehingga $F_{\text {tabel }}=3,10$. Sehingga dapat dikatakan variabel bebas (PDRB, BI Rate dan IPM) mempengaruhi variabel terikat (Tabungan) secara bersama sama. Dimana nilai sinifikansinya $0,00004<0,05$ dan nilai $F_{\text {hitung }}$ $(99,88119)>\mathrm{F}_{\text {tabel }}(3,10)$.

Estimation Command:

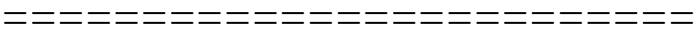

\section{LS Y C X1 X2 X3}

Estimation Equation:

=ニニニニニニニニニニニニニニニニニニニニ

$\mathrm{Y}=\mathrm{C}(1)+\mathrm{C}(2) * \mathrm{X} 1+\mathrm{C}(3) * \mathrm{X} 2+\mathrm{C}(4) * \mathrm{X} 3$

Substituted Coefficients:

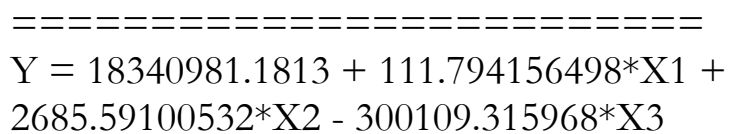




\section{Analisis Data Panel}

Pemilihan Teknik Estimasi Regresi Data Panel

Dari pendekatan estimasi Common Effect Model, Fixed Effect Model, dan Random Effect Model ditentukan teknik terbaik yang akan digunakan untuk regresi data panel dengan uji chow dan uji hausman.

\section{Common Effect Model (CEM)}

Hasil regresi menggunakan Common Effect Model:

Tabel 3. Hasil Common Effect Model

\begin{tabular}{|c|c|c|c|c|}
\hline Variable & Coefficient & Std. Error & $\mathrm{t}$-Statistic & Prob. \\
\hline C & $-2.34 E+08$ & 36372882 & -6.431204 & 0.0000 \\
\hline$x 1$ & -1.183242 & 0.502115 & & 0.0223 \\
\hline$x 2$ & 1178863. & 1407934. & 0.837300 & 0.4063 \\
\hline$\times 3$ & 3259035 . & 450029.2 & 7.241829 & 0.0000 \\
\hline Root MSE & 12536984 & \multirow{7}{*}{\multicolumn{2}{|c|}{$\begin{array}{l}\text { R-squared } \\
\text { Adjusted R-squared } \\
\text { S.E. of regression } \\
\text { Sum squared resid } \\
\text { Log likelihood } \\
\text { F-statistic } \\
\text { Prob(F-statistic) }\end{array}$}} & 0.538080 \\
\hline Mean dependent var & 11881582 & & & 0.510908 \\
\hline S.D. dependent var & 18616325 & & & 13019350 \\
\hline Akaike info criterion & 35.67172 & & & $8.64 E+15$ \\
\hline Schwarz criterion & 35.81771 & & & -976.9723 \\
\hline Hannan-Quinn criter. & 35.72817 & & & 19.80288 \\
\hline Durbin-Watson stat & 0.046373 & & & 0.000000 \\
\hline
\end{tabular}

\section{Fixed Effect Model (FEM)}

Hasil regresi menggunakan Fixed Effect Model:

\section{Tabel 4. Fixed Effect Mode}

Dependent Variable: $Y$

Method: Panel Least Squares

Date: 08/05/21 Time: 11:20

Sample: 20102020

Periods included: 11

Total panel (balanced) observations: 55

\begin{tabular}{crrrr}
\hline \hline Variable & Coefficient & Std. Error & t-Statistic & Prob. \\
\hline \hline C & -35572068 & 22128141 & -1.607549 & 0.1146 \\
X1 & -0.558156 & 0.440696 & -1.266533 & 0.2116 \\
X2 & -722489.3 & 377040.4 & -1.916212 & 0.0614 \\
X3 & 712553.0 & 286481.6 & 2.487255 & 0.0165 \\
\hline \multicolumn{5}{c}{ Effects Specification } \\
\hline \hline
\end{tabular}

Cross-section fixed (dummy variables)

\section{Root MSE}

Mean dependent var

S.D. dependent var

Akaike info criterion

Schwarz criterion

Durbin-Wats on stat

2772729. R-squared

18616325 Adjusted R-squared

32.79047 S.E. of regression

32.79947 Sum squared resid

32.91238 F-statistic

0.275046 Prob(F-statistic)

\subsection{6} 0.974041 2999438. $4.23 \mathrm{E}+14$ 290.4550 0.000000

\section{Uji Chow}

Uji chow dilakukan untuk mengetahui model terbaik antara common effect dan fixed effect :

Tabel 5. Hasil Uji Chow

\begin{tabular}{|l|l|l|l|}
\hline \multicolumn{4}{|l|}{ Redundant Fixed Effects Tests } \\
\hline \multicolumn{4}{|l|}{ Equation: Untitled } \\
\hline \multicolumn{4}{|l|}{ Test cross-section fixed effects } \\
\hline Effects Test & Statistic & d.f. & Prob. \\
\hline $\begin{array}{l}\text { Cross-section } \\
\text { F }\end{array}$ & 228.469981 & $(4,47)$ & 0.0000 \\
\hline $\begin{array}{l}\text { Cross-section } \\
\text { Chi-square }\end{array}$ & 165.973602 & 4 & 0.0000 \\
\hline
\end{tabular}

Berdasarkan uji chow di atas diperoleh nilai Signifikansi dari cross section Chi-square dan cross section F sebesar 0.0000 (kurang dari 5\%), sehingga secara statistik Ho ditolak dan menerima $\mathrm{Ha}$, maka model estimasi yang tepat digunakan pada regresi data panel adalah Fixed Effext Model.

\section{Random Effect Model (REM)}

Hasil regresi menggunakan Random Effect Model:

Tabel 6. Hasil Random Effect Model

\begin{tabular}{|c|c|c|c|c|}
\hline Variable & Coefficient & Std. Error & $t$-Statistic & Prob. \\
\hline \multirow[t]{2}{*}{$\begin{array}{l}c \\
\times 1 \\
\times 2 \\
\times 3 \\
\times 3 \\
\end{array}$} & $\begin{array}{r}-39567925 \\
-0.608679 \\
-691065.2 \\
765289.5\end{array}$ & $\begin{array}{r}23373826 \\
0.432896 \\
376274.5 \\
283397.4\end{array}$ & $\begin{array}{r}-1.692830 \\
-1.406060 \\
-1.836599 \\
2.700411\end{array}$ & $\begin{array}{l}0.0966 \\
0.1658 \\
0.0721 \\
0.0094 \\
\end{array}$ \\
\hline & \multicolumn{2}{|c|}{ Effects Specification } & S.D. & Rho \\
\hline \multicolumn{3}{|l|}{$\begin{array}{l}\text { Cross-section random } \\
\text { ldiosyncratic random }\end{array}$} & $\begin{array}{c}18225003 \\
2999438 .\end{array}$ & $\begin{array}{l}0.9736 \\
0.0264 \\
\end{array}$ \\
\hline \multicolumn{5}{|c|}{ Weighted Statistics } \\
\hline $\begin{array}{l}\text { Root MSE } \\
\text { Meand dependent var } \\
\text { S.D. dependent var } \\
\text { Sum squared resid } \\
\text { Durbin-Watson stat } \\
\end{array}$ & $\begin{array}{l}2881901 . \\
588865.5 \\
3471461 \\
4.5716+14 \\
0.250665 \\
\end{array}$ & \multicolumn{2}{|c|}{ 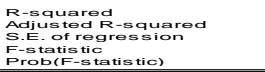 } & $\begin{array}{l}0.298056 \\
0.256765 \\
2992784 \\
7.218444 \\
0.000396 \\
\end{array}$ \\
\hline \multicolumn{5}{|c|}{ Unweighted Statistics } \\
\hline $\begin{array}{l}\text { R-squared } \\
\text { Sum squared resid }\end{array}$ & $\begin{array}{r}0.245843 \\
1.41 E+16 \\
\end{array}$ & $\begin{array}{l}\text { Mean depen } \\
\text { Durbin-Wats }\end{array}$ & $\begin{array}{l}\text { ent var } \\
\text { nstat }\end{array}$ & $\begin{array}{r}11881582 \\
0.008113 \\
\end{array}$ \\
\hline
\end{tabular}

\section{Uji Hausman}

Hipotesis pada uji hausman adalah sebagai berikut:

Tabel 7. Hasil Uji Hausman

Correlated Random Effects - Hausman Test

\begin{tabular}{|c|c|c|c|c|}
\hline \multicolumn{2}{|c|}{ Test Summary } & $\begin{array}{l}\text { Chi-Sq. } \\
\text { Statistic }\end{array}$ & Chi-Sq. d.f. & Prob. \\
\hline \multicolumn{2}{|c|}{$\begin{array}{l}\text { Cross-section } \\
\text { random }\end{array}$} & 1.773980 & 3 & $\begin{array}{l}0.620 \\
6\end{array}$ \\
\hline \multicolumn{5}{|c|}{ Cross-section random effects test comparisons: } \\
\hline $\begin{array}{l}\text { Variabl } \\
\mathrm{e}\end{array}$ & Fixed & Random & $\operatorname{Var}($ Diff.) & Prob. \\
\hline $\mathrm{X} 1$ & -0.558156 & -0.608679 & -0.608679 & $\begin{array}{l}0.540 \\
5\end{array}$ \\
\hline $\mathrm{X} 2$ & $-722489 \ldots$. & $\begin{array}{l} \\
691065.2 \ldots\end{array}$ & $\begin{array}{l}576983186 . \\
. .\end{array}$ & $\begin{array}{l}0.190 \\
8\end{array}$ \\
\hline $\mathrm{X} 3$ & 712552.9.. & $\begin{array}{l}765289.52 . \\
. .\end{array}$ & $17576254 \ldots$ & $\begin{array}{l}0.208 \\
4\end{array}$ \\
\hline \multicolumn{5}{|c|}{ Cross-section random effects test equation: } \\
\hline $\begin{array}{l}\text { Variabl } \\
\mathrm{e}\end{array}$ & $\begin{array}{l}\text { Coefficie } \\
\text { nt }\end{array}$ & Std. Error & t-Statistic & Prob. \\
\hline $\mathrm{C}$ & - 35572068 & 22128141 & -1.607549 & $\begin{array}{l}0.114 \\
6\end{array}$ \\
\hline $\mathrm{X} 1$ & -0.558156 & 0.440696 & -1.266533 & $\begin{array}{l}0.211 \\
6\end{array}$ \\
\hline $\mathrm{X} 2$ & -722489.3 & 377040.4 & -1.916212 & $\begin{array}{l}0.061 \\
4\end{array}$ \\
\hline X3 & 712553.0 & 286481.6 & 2.487255 & $\begin{array}{l}0.016 \\
5\end{array}$ \\
\hline
\end{tabular}

Berdasarkan uji hausman, nilai Signifikansi dari cross section random sebesar 0,6206 (lebih besar dari 0,05$)$ sehingga secara statistik Ho diterima dan menolak Ha, maka model estimasi yang

151 | Jurnal Ekonomi dan Manajemen Teknologi Vol. 5 | No. 2 | 2021 
tepat digunakan pada regresi data panel pada penelitian ini adalah Random Effect Model.

\section{Hasil Estimasi Regresi Random Effect Model (REM).}

Berdasarkan hasil regresi Random Effect Model, maka dapat dituliskan persamaan model regresi antara variabel terikat (Tabungan) dan variabel bebas (PDRB, BI Rate dan IPM) sebagai berikut:

Yit $=-39567925-0.558156$ PDRBit -722489.3

BIit + 712553.0 IPMit

\section{Pengujian Hipotesis}

Hasil Uji Koefisien Determinasi (R-Square)

Diketahui nilai R-square sebesar 0,298056 atau setara 30\%. Hal ini menunjukkan bahwa variasi variabel terikat tabungan secara simultan dapat dijelaskan oleh variabel independen (PDRB, BI Rate dan IPM) sebesar 30\% sedangkan sisanya $70 \%$ dijelaskan oleh faktor lain diluar variabel yang diteliti. Karena nilai R-squared yang didapat dalam penelitian ini kecil berarti kemampuan variabel-variabel independen menjelaskan variabel dependen terbatas. Hal ini terjadi karena didalam model penelitian hanya ada satu variabel yang memiliki pengaruh signifikan terhadap Tabungan yaitu variabel IPM.

\section{Hasil Uji F (Uji Simultan)}

Hipotesis uji $\mathrm{F}$ pada penelitian ini adalah sebagai berikut:

Ho : PDRB, BI Rate dan IPM secara bersama-sama tidak berpengaruh terhadap Tabungan.

$\mathrm{Ha}$ : PDRB, BI Rate dan IPM secara bersama-sama berpengaruh terhadap Tabungan.

Berdasarkan $\mathrm{t}$ hitung atau t-statistik sebesar 7.218446 dengan nilai signifikansi sebesar 0,000396 yang artinya $<0,05$ sehingga $\mathrm{Ha}$ diterima dan dapat disimpulkan bahwa variabel PDRB, Bi Rate dan IPM secara simultan berpengaruh signifikan terhadap tabungan.

\section{Hasil Uji t (Uji Parsial)}

Pengaruh PDRB terhadap tabungan berdasarkan hasil uji t di atas diperoleh nilai tstatistik PDRB -1.406060 dengan arah negatif dan nilai signifikansi BI Rate sebesar 0,1658 >
0,05. Hipotesis untuk Bi rate pada penelitian ini adalah:

Ho : BI Rate tidak berpengaruh positif dan signifikan terhadap Tabungan.

$\mathrm{Ha}$ : BI Rate berpengaruh positif dan signifikan terhadap Tabungan.

Hasil diatas memperlihatkan bahwa Ho diterima, maka dapat disimpulkan bahwa PDRB tidak berpengaruh terhadap tabungan. Pengaruh BI Rate terhadap tabungan berdasarkan hasil uji $\mathrm{t}$ di atas diperoleh nilai t-statistik BI Rate 1.836599 dengan arah negatif dan nilai signifikansi BI Rate sebesar 0,0721 > 0,05. Hipotesis untuk BI Rate pada penelitian ini adalah:

Ho : BI Rate tidak berpengaruh positif dan signifikan terhadap tabungan.

$\mathrm{Ha}$ : BI Rate berpengaruh positif dan signifikan terhadap tabungan.

Berdasarkan data diatas bahwa Ho diterima. Namun pada toleransi $\alpha 10 \%$ Nilai BI Rate signifikan. Maka dapat disimpulkan bahwa BI Rate tidak berpengaruh terhadap tabungan pada taraf signifikansi 0,05 sedangkan pada taraf signifikansi 10\% BI rate berpengaruh signifikan terhadap tabungan. Pengaruh IPM terhadap tabungan berdasarkan hasil uji $t$ di atas diperoleh nilai t-statistik IPM 2700411 dengan arah negatif dan nilai signifikansi IPM sebesar $0,0094>0,05$. Hipotesis untuk IPM pada penelitian ini adalah:

Ho : IPM tidak berpengaruh positif dan signifikan terhadap tabungan.

$\mathrm{Ha}$ : IPM berpengaruh positif dan signifikan terhadap tabungan.

Data diatas menunjukkan bahwa Ha diterima dan dapat disimpulkan bahwa IPM berpengaruh signifikan terhadap tabungan.

\section{Pembahasan}

Hasil analisa dalam penelitian ini terdiri dari dua yaitu analisis hasil regresi linier berganda pada Kabupaten Langkat dan analisis Dana Panel Terhadap 5 Kabupaten Kota di Sumatera Utara. Dari hasil pengujian hipotesis, baik secara simultan maupun dengan pengujian secara parsial secara ringkas dapat dijelaskan sebagai berikut: 
Pengarub variabel PDRB terhadap variabel tabungan. Hasil Analisis pengaruh PDRB terhadap Tabungan masyarakat pada bank di Kabupaten Langkat mempunyai pengaruh dan signifikan. Hal ini disebabkan pendapatan masyarakat di Kabupaten Langkat digunakan sesuai dengan teori bahwa pendapatan merupakan fungsi dari konsumsi ditambah tabungan ditambah investasi. Sehingga jika pendapatan masyarakat yang tercermin melalui PDRB meningkat maka akan berdampak pada peningkatan jumlah tabungan masyarakat. Hal ini sesuai dengan hasil penelitian (Duran et al., 2017) menunjukkan bahwa tingkat pengangguran dan pertumbuhan produk domestik bruto (PDB) per kapita menonjol dengan tingkat hubungan yang relatif tinggi, rasio keseimbangan dan pertumbuhan PDB dipastikan sebagai indikator yang memiliki tingkat hubungan yang tinggi dengan tabungan domestik. Namun hasil yang berbeda terjadi jika dilakukan regresi data panel terhadap 5 Kabupaten/Kota yang ada di Sumatera Utara dengan hasil bahwa PDRB tidak berpengaruh signifikan terhadap Tabungan Masyarakat. Hal tersebut dikarenakan jumlah pendapatan masyarakat di Provinsi Sumatera Utara khususnya yang tinggal di perkotaan memiliki dimensi yang berbeda baik dari jumlah pendapatannya dan penggunaannya.

\section{Pengaruh variabel BI Rate terbadap variabel tabungan.}

Analisis pengaruh BI Rate terhadap Tabungan masyarakat di Kabupaten Langkat Tidak berpengaruh signifikan. Hal ini dikarenakan tujuan utama masyarakat Kabupaten Langkat dalam menabung adalah untuk fungsi berjagajaga, sehingga tidak terlalu memperhatikan nilai suku bunga yang ditawarkan oleh pihak perbankan. Hal ini sesuai dengan penelitian (Hong et al., 2020) hasil utama penelitian menunjukkan bahwa suku bunga secara umum meningkat atau menurun setelah deregulasi suku bunga pinjaman, namun perubahan tersebut tidak signifikan untuk menimbulkan dampak negatif terhadap perekonomian domestik. Sedangkan pada analsisis data penel terhadap 5 Kabupaten Kota di Sumatera Utara BI rate memiliki pengaruh signifikan pada taraf signifikansi $10 \%$. Masyarakat yang tinggal diperkotaan sudah lebih mempertimbangkan
BI rate dalam menempatkan dananya di bank dalam bentuk Tabungan. Penelitian yang dilakukan (Pan \& Ha, 2020) menunjukkan bahwa perubahan dalam arti-penting suku bunga pinjaman mempengaruhi hubungan antara orientasi pelanggan dan loyalitas, bank harus cepat menjelaskan berapa banyak uang yang diperlukan ketika kesadaran konsumen akan perubahan suku bunga pinjaman. Hal ini menjelaskan bahwa perubahan BI rate mempengaruhi perilaku nasabah dalam menabung.

\section{Pengaruh variabel IPM terhadap variabel tabungan.}

Analisis pengaruh IPM terhadap Tabungan Masyarakat di Kabupaten Langkat berpengaruh signifikan. Hal ini dikarenakan pengetahuan terhadap fungsi menabung dibank akan semakin baik dengan meningkatnya nilai IPM. Dengan meningkatnya IPM maka secara tidak langsung literasi terkait pengetahuan masyarakat mengenai perbankan dan manfaat menabung akan meningkat. Pada analisis data panel juga menunjukkan hal yang sama dimana di 5 Kabupaten Kota di Sumatera Utara menunjukkan hasil bahwa apabila terjadi peningkatan IPM maka akan berdampak pada peningkatan jumlah tabungan masyarakat di bank. Hal ini sesuai dengan hasil penelitian (Susan, 2020) yang menyatakan bahwa literasi keuangan berpengaruh positif terhadap Akses Keuangan (menabung dan pembiayaan) dan Pertumbuhan UMKM, dan Akses Keuangan juga berpengaruh positif terhadap Pertumbuhan UMKM. Dimana tingkat IPM menggambarkan pengetahuan secara umum, sehingga pengetahuan keuangan bagian penting dari pertumbuhan tabungan bank.

\section{Kesimpulan}

Dari uraian pendahuluan, metode penelitian, hasil analisis dan pembahasan, maka dapat disimpulkan bahwa terdapat pengaruh signifikan variabel IPM terhadap tabungan masyarakat Sumatera Utara. Variabel PDRB tidak berpengaruh terhadap tabungan masyarakat Sumatera Utara. Selanjutnya variabel BI Rate juga tidak berpengaruh terhadap tabungan namun pada taraf signifikansi 10\% berpengaruh terhadap tabungan. Secara simultan variabel PDRB, BI Rate dan IPM 
berpengaruh terhadap tabungan. Temuan lainnya yang diperoleh pada penelitian ini adalah terdapat pengaruh signifikan variabel PDRB terhadap tabungan masyarakat di Kabupaten Langkat dan terdapat pengaruh signifikan variabel IPM terhadap tabungan masyarakat di Kabupaten Langkat. Sedangkan variabel BI Rate tidak berpengaruh terhadap tabungan masyarakat Kabupaten Langkat. Selanjutnya secara bersama-sama variabel eksogen berpengaruh sangat signifikan terhadap tabungan masyarakat di Kabupaten Langkat.

\section{Daftar Pustaka}

Amari, M., Salhi, B., \& Jarboui, A. (2020). Evaluating the effects of sociodemographic characteristics and financial education on saving behavior. International Journal of Sociology and Social Policy, $\quad 40(11-12)$, 1423-1438. https://doi.org/10.1108/IJSSP-032020-0048

Ariyati, I., Agustina, F., \& Miliani T, G. (2021). Sistematic Literature Review: Pengaruh Literasi Keuangan Terhadap Kinerja Umkm Di Indonesia. Jurnal Ekonomika: Manajemen, Akuntansi, Dan Perbankan Syariah, 10(1), 104-118. https://doi.org/10.24903/je.v10i1.1337

Bodenhorn, H. (2018). The forgotten half of finance: Working-class saving in late nineteenth-century New Jersey. In Research in Economic History (Vol. 34). https://doi.org/10.1108/S0363326820180000034002

Duran, E., Uzgur Duran, B., Akay, D., \& Boran, F. E. (2017). Grey relational analysis between Turkey's macroeconomic indicators and domestic savings. Grey Systems: Theory and Application, $\quad 7(1)$, 45-59. https://doi.org/10.1108/gs-10-20160039
Earl, P. E. (2001). The Psychology of Saving: A Study on Economic Psychology; KarlErik Wärneryd; Edward Elgar, Cheltenham, 1999; pp. ix + 389, ISBN 1 840640162 (65.00). Journal of Economic Psychology, 22(2), 295-299. https://doi.org/10.1016/s01674870(00)00038-6

Eriksson, K., \& Hermansson, C. (2014). Searching for new saving behavior theories. International Journal of Bank Marketing, 32(4), 279-299. https://doi.org/DOI 10.1108/IJBM-032014-0040

Eriksson, K., \& Hermansson, C. (2019). How relationship attributes affect bank customers' saving. International Journal of Bank Marketing, 37(1), 156-170. https://doi.org/10.1108/IJBM-09-20170194

Fuadi, F., \& Munandar, M. (2020). Pengaruh Awareness Terhadap Niat Nasabah Menggunakan Produk Perbankan Syariah pada BNI Syariah Lhokseumawe dengan Media Communication Sebagai Pemoderasi. Jurnal EMT KITA, 4(2), 105. https://doi.org/10.35870/emt.v4i2.147

Harahap, M. A., \& Hafizh, M. (2020). Pengaruh Pembiayaan Bank Syariah, Suku Bunga dan GDP Terhadap Uang Beredar di Indonesia. Al-Sharf Jurnal Ekonomi Islam, 1(1), 64-86. https://doi.org/10.30596/alsharf.v

Haron, S., \& Nursofiza Wan Azmi, W. (2008). Determinants of Islamic and conventional deposits in the Malaysian banking system. Managerial Finance, 34(9), 618-643.

https://doi.org/10.1108/0307435081089 0976

Harun, C. A., \& Nattan, R. R. (2019). Non-core deposit of Indonesian banking. Studies in Economics and Finance, 38(2), 207-226. https://doi.org/10.1108/SEF-10-20180311 
Hondroyiannis, G. (2004). Estimating private savings behaviour in Greece. Journal of Economic Studies, 31(5), 457-476. https://doi.org/10.1108/014435804105 55555

Hong, H., Bian, Z., Chen, N., \& Su, C. (2020). Does interest rate liberalisation affect the constancy of mean interest rates in China? Journal of Financial Regulation and Compliance, 28(4), 555-568. https://doi.org/10.1108/JFRC-10-20190129

Klasjok, K., Rotinsulu, T. O., \& Maramis, M. T. . (2018). Tabungan Masyarakat Pada Bank Umum Di Papua Barat ( Periode Tahun 2008-2017 ) Analysis Of Factors Influencing Public Savings In KristinaKlasjok. Jurnal Berkala Ilmiah Efisiensi, 18(03), 58-67. https://ejournal.unsrat.ac.id/index.php/ jbie/article/view/20259/19866

Mori, N. (2019). Determinants of individual savings among Tanzanians. Review of Behavioral Finance, 11(3), 352-370. https://doi.org/10.1108/RBF-05-20180045

Narayan, P. K., \& Narayan, S. (2006). Savings behaviour in Fiji: An empirical assessment using the ARDL approach to cointegration. International Journal of Social Economics, 33(7), 468-480. https://doi.org/10.1108/030682906106 73243

Oberholster, S. J. (2010). War on savings: Modern monetary management in crisis. Journal of Financial Regulation and Compliance, 18(3), 201-223. https://doi.org/10.1108/135819810110 60790
Pan, H., \& Ha, H. Y. (2020). When do interest rates matter? Two methodological approaches to loyalty. Asia Pacific Journal of Marketing and Logistics, 32(1), 46-64. https://doi.org/10.1108/APJML-062018-0229

Riyanto, A., Adriani, A., \& Norlena. (2021). Pengaruh Mekanisme Good Corporate Governance Dan Pengungkapan Tanggung Jawab Sosial Perusahaan Terhadap Praktik Manajemen Laba. Jurnal Ekonomika: Manajemen, Akuntansi, Dan Perbankan Syariah, 10(1), 27-48. https://doi.org/10.24903/je.v10i1.1212

Sara Jonsson Inga-Lill Söderberg Mats Wilhelmsson. (2017). An investigation of the impact of financial literacy, risk attitude, and saving motives on the attenuation of mutual fund investors' disposition bias. Managerial Finance, 43(3), $1-12$.

https://doi.org/https://doi.org/10.1108 /MF-10-2015-0269

Suppakitjarak, N., \& Krishnamra, P. (2015). Household Saving Behavior and Determinants of the Forms of Saving and Investment in Thailand. Journal of Economics, Business and Management, 3(3), 326-330. https://doi.org/10.7763/joebm.2015.v3. 204

Susan, M. (2020). Financial literacy and growth of micro, small, and medium enterprises in west java, indonesia. International Symposia in Economic Theory and Econometrics, 27, 39-48. https://doi.org/10.1108/S1571038620200000027004

Tobing, F. (2014). Analisis Faktor-Faktor yang Mempengarubi Jumlab Tabungan di Indonesia: Vol. Vol. 2 (No (pp. 29-39). http://repository.uki.ac.id/351/1/Jurnal Fery 3.pdf 
Yumna, A. (2019). Examining financial needs of banking customers for product development in Islamic banking in Indonesia: A Maslahah pyramid approach. International Journal of Islamic and Middle Eastern Finance and Management, 12(5),

712-726. https://doi.org/10.1108/IMEFM-112018-0378
Zakaria, Z., \& Ismail, M. R. (2017). Financial Literacy and Risk Tolerance towards Saving and Investment: A Case Study in Malaysia. International Journal of Economics and Financial, 7(4), 507-514. file://C:/Users/HP/Downloads/511313443-1-PB.pdf 